\title{
Students' scientific attitude during the Implementation of innovative green garden-based education
}

\author{
Desy Fajar Priyayi a,1,*, Gamaliel Septian Airlanda ${ }^{\mathrm{b}, 2}$, Dina Rotua V. Banjarnahor $\mathrm{c}, 3$ \\ a Department of Biology Education, Faculty of Biology, Universitas Kristen Satya Wacana, JI Diponegoro No. 52-60, Salatiga, \\ Central Java, 50711, Indonesia \\ b Department of Primary School Teacher Education, Faculty of Teacher Training and Education, Universitas Kristen Satya Wacana, \\ JI Diponegoro No. 52-60, Salatiga, Central Java 50711, Indonesia \\ Department of Agrotechnology, Faculty of Agriculture and Business, Universitas Kristen Satya Wacana, JI Diponegoro No. 52-60, \\ Salatiga, Central Java 50711, Indonesia \\ ${ }^{1}$ desy.priyayi@uksw.edu*; ${ }^{2}$ gamaliel.septian@uksw.edu; ${ }^{3}$ dina.banjarnahor@uksw.edu \\ * Corresponding author
}

\begin{tabular}{|c|c|}
\hline ARTICLE INFO & ABSTRACT \\
\hline \multirow[t]{2}{*}{$\begin{array}{l}\text { Article history } \\
\text { Received February } 27,2020 \\
\text { Revised June } 02,2020 \\
\text { Accepted June } 18,2020 \\
\text { Published July } 21,2020 \\
\text { Keywords } \\
\text { Green garden-based education } \\
\text { Scientific attitudes } \\
\text { Science learning model }\end{array}$} & $\begin{array}{l}\text { Scientific attitudes are considereble aspect to observe in science learning. This study } \\
\text { aimed to analyze students' scientific attitudes. In accordance with this aim, the students' } \\
\text { and teachers' perceptions were recorded. This study was conducted in Junior High } \\
\text { School } 8 \text { Salatiga. The sample of this research was } 33 \text { students and four science } \\
\text { teachers. Furthermore, the quantitative data of scientific attitudes were collected using a } \\
\text { questionnaire which than were analyzed using mean score. Meanwhile, the qualitative } \\
\text { data of students' scientific attitudes and perceptions were collected by interviewing } \\
\text { students and teachers. The results of the study showed that the scientific attitudes were } \\
\text { catagorized in the range of mean score from } 3.2 \text { to } 4.7 \text {. In addition, the students and } \\
\text { teachers showed positive perceptions. To sum up, the green garden-based education } \\
\text { could be an alternative model in science learning. }\end{array}$ \\
\hline & $\begin{array}{l}\text { Copyright } \odot \text { 2020, Priyayi et al } \\
\text { This is an open access article under the CC-BY-SA license }\end{array}$ \\
\hline $\begin{array}{r}\text { How to cite: Priyayi, D. F., A } \\
\text { of innovative gr } \\
\text { doi.org/10.2221 }\end{array}$ & $\begin{array}{l}\text { S., \& Banjarnaroh, D. R. V., (2020). Students' scientific attitude during the implementation } \\
\text { en-based education. JPBI (Jurnal Pendidikan Biologi Indonesia), 6(2), 293-304. doi: https:// } \\
2.11402\end{array}$ \\
\hline
\end{tabular}

\section{INTRODUCTION}

Science education develops science knowledge; hence science processes skills and scientific attitudes among the students. The development of the students' scientific attitude is one of the most important learning outcomes of science education. Also, the 2013 Indonesia curriculum emphasizes the importance of developing students' scientific attitudes including curiosity, honesty, logic, critical thinking, discipline, and responsibility. Many attempts over the last five decades to measure students' attitudes towards school science, scientific attitudes should be a major concern of science teachers. The entire personality of student is influenced by the nature of the attitudes (Balaji, 2017; Kennedy, Quinn, Taylor, Quinn, \& Taylor, 2016)

Scientific attitude is characteristic of a scientist. Scientific attitude is explained as the mental state, representing a tendency to react favorably or unfavorable toward designated class of stimuli according to the 
ethics of science (Pitafi, Pur, \& Farooq, 2012). Revati \& Meera (2017) define scientific attitude as solving a problem objectively, without bias using logical thinking. Korur (2016) measured the scientific attitudes in relation with curiosity, critical thinking, proof dependent, persistency, co-operation, objectivism, and acceptance of uncertainty. Ural \& Gençoğlan (2020) emphasized three basic components of scientific attitudes including belief, feeling, and action. The belief and feeling towards science leads someone to act. To conclude, scientific attitude can be explained as complex values and norms which is internalized by the man of science. Some of the elements of scientific attitude are open-mindedness, rationality, curiosity, critical thinking, cooperation, honesty, and persistency (Lacap, 2015; Pitafi et al., 2012). The importance of attitude may be inferred from the fact that attitudes determine behavior (Pitafi, et al., 2012). Scientific attitude can help the students solve problems objectively (Kaur, 2013). Lacap (2015) concludes that there is a significant relationship between academic performance and scientific attitudes. Scientific attitudes have an important role in developing scientific literacy (Korur, 2016).

On the contrary, based on the PISA (Program for International Student Assessment) result, Indonesia was faired poorly in science compared to all the other countries in the world. Indonesia was ranked $63^{\text {rd }}$ from the 65 countries reviewed in 2012 and $62^{\text {nd }}$ from 70 countries in 2015. The results of surveys, interviews, and observations toward science teachers and students in the junior high school 8 Salatiga as one of the public school in Indonesia that promote "adiwiyata" or green school program showed that the scientific attitude students had not developed optimally. The curiosity and critical attitude of students towards natural phenomena around them is still low. This is proven by the attitude of students who rarely ask question from the teacher during science learning. Students tend to be passive and wait for the teacher's command to do something. Students do not have the initiative to find out information through books.

According to the teacher's explanation the students' scientific attitudes are still low because of: 1) the lack of learning media that support the development of scientific attitudes; 2) the limited opportunities for teachers to develop the learning media; 3 ) the lack of assistance to teachers regarding the development of learning media; and, 4) the lack of assistance to students in science learning. Actually, some teachers already have applied various science learning models in the class, such as direct instruction and some of cooperative learning models. However, the teachers stated that these models have not been able to increase students' awareness to be disciplined, critical, responsible, and curious because of the limitation of learning media. Consequently, it is necessary to provide a learning media that can enhance the students' scientific attitude. As one of the alternatives, teachers can implement the innovative green garden-based education during the science learning process (Macquarrie, 2016; Wolsey \& Lapp, 2014).

The innovative green garden-based education can become an instructional strategy that utilizes a garden as an instructional resource, a teaching tool. It has components that are close to the lives of students. If students are familiar with the components that they learn, it is expected that students will more easily and actively manage the gardens in the school. Much attention has recently been paid to children's learning outside the classroom (Harris, 2015; Harris \& Bilton, 2018; Prince, 2018). Outdoor learning is not a new perspective; there have been many scholars who have endorsed thebenefits of children having experiences of this natural learning environment (Davies \& Hamilton, 2016). Based on Alderson, Hempel, \& Olson (2015) school garden has common focus on growing plants in a few pots or in schoolyard. Gardening programs are flexible in all shapes and sizes fit with the needs and resources of every school. In this research, the innovative green garden-based education adopted by the school garden initiated by Food and Agriculture Organization of The United Nations (FAO, 2009).

The innovative green garden uses soil and non-soil planting media (rock wool, perlite, or coco peat). The use of different planting media will lead to variations in natural processes because the planting media material has different chemical structures, characters and types of microorganisms (Best, et al., 2014; Grunert, et al., 2016). The plants chosen are those that are easy to grow, have a good taste (if for consumption), have attractive colors and shapes, and are suitable for the weather and geographical conditions in Salatiga. Plants for consumption must support students' nutrition, for example vegetables and fruit. Student involvement in school garden activities can increase students' willingness to taste vegetables, increase students' appreciation of vegetable flavor (Morgan et al., 2017; Triador, Farmer, Maximova, Willows, \& Kootenay, 2015), increase the variety of vegetables consumed by students (Leuven, Rutenfrans, Dolfing, \& Leuven, 2018), and increase the amount of vegetables consumed (Kim \& Park, 2020; Soga, Gaston, \& Yamaura, 2016)

The green garden-based education model emphasizes the active participation of students in planning, manufacturing, and maintaining gardens. The garden contains various components of living things (plants and animals) and nonliving-things (soil, organic matter, and water). All of these components interact to form natural processes such as the food chain, and the growth, development, and decomposition of living things. This phenomenon can be observed directly by students. Through observing these natural phenomena, students can learn science concepts in a real way. The green garden-based education criteria as contextual science learning 
media are described as follows: It has biotic components (plants and animals) and abiotic (water, soil planting media, non-soil planting media). Learning in the school garden can improve students' understanding of plant identification (Passy, 2012; Somerset \& Markwell, 2017).

Learning throughout green garden-based education component, students can recognize various kinds of living things, environmental components, and interactions and natural processes that occur. Hands-on learning that is conducted in garden-based learning process has been shown to be an important component in involving student in experiential learning is also found to help promote higher-level learning (Bento \& Dias, 2017). Also, the participation of the students when they are learning science through innovative green garden is expected to develop students' scientific attitude. The school garden can be an effective teaching tool that promotes handson activities. It provides dynamic environments that help the students to observe, discover, investigate, and learn. The students become an active participants learning science in the real-life experiences. They gain the knowledge of plant and animal life cycles, an appreciation for ecosystems, food origins and nutrition (Alderson et al., 2015).

Many studies on scientific attitude have been done but study about the scientific attitude of students during the implementation of innovative green garden- based education in Indonesia has not been explained much. In general, the science learning process is conducted in the classroom. However, many benefits can be reached when the student can experience their knowledge directly in the environment, for example, if they study science through innovative green garden. The research aimed to address the students' scientific attitude toward the implementation of innovative green garden-based education at junior high school 8 Salatiga also the teachers' and students' perceptions about the implementation of innovative green garden-based education at junior high school 8 Salatiga.

\section{METHOD}

This is a case study that determined the student's scientific attitudes toward the implementation of innovative green garden-based education and the perception of teachers and students toward the implementation of innovative green garden-based education. The study was conducted from June 2018 December 2018. The sample of this study was targeted and convenient. The respondents consisted of the 33 students that join innovative green garden-based education course as extracurricular activity in the junior high school 8 Salatiga and four teachers who teach Science. The school is one of 'adiwiyata' school that promote the importance of green school program. The head school and the teachers gave clearance to conduct this research. The respondents were not subjected to protect their identity.

The mixed methods design was used in this study. Quantitative data was gathered through scientific attitude questionnaire that was adopted from Korur, (2016) and Pitafi et al., (2012). The questionnaire consists of the scientific attitude elements which are: curiosity, dependent on proofs (rationality, open mindedness, critical thinking), cooperation, honesty, and persistency. The reliability of the questionnaire (Cronbach Alpha) was 0.87 , which is considered as higher for studies in education and social sciences (Table 1). Final version of scale consisted of 20 positives and 8 negative items out of 28 total using Likert scale with 1-5 category with 5 as strongly agree, and 1 as strongly disagree for positive items. The negative statements are scored inversely. The mean score of each questionnaire item was calculated. Each element of scientific attitude was categorized based on Pitafi et al. (2012) presentation. The element with mean score below 3.0 means negative attitude, 3.0 as neutral attitude, 3.1 to 3.5 as slightly positive attitude, 3.6 to 4.5 as moderately positive and 4.6 to 5.0 as highly positive attitude. The questionnaire was distributed after the innovative green garden-based education course had been finished.

Table 1. The scientific attitude elements and the reliability of scientific attitude questionnaire

\begin{tabular}{|c|c|c|c|c|c|}
\hline \multirow[t]{2}{*}{ Elements } & \multicolumn{2}{|c|}{ Item (s) retains } & \multirow{2}{*}{$\begin{array}{l}\mathrm{N} \text { of } \\
\text { items }\end{array}$} & \multirow{2}{*}{$\begin{array}{c}\text { Reliability } \\
\text { (Cronbach's Alpha) }\end{array}$} & \multirow{2}{*}{$\begin{array}{c}\text { Internal } \\
\text { Consistency }\end{array}$} \\
\hline & Positive & Negative & & & \\
\hline Curiosity & $8,10,27$ & 20 & \multirow{8}{*}{28} & \multirow{8}{*}{0.87} & \multirow{8}{*}{ Good } \\
\hline Dependent of proofs & & & & & \\
\hline - Rationality & $5,7,15,17,26$ & & & & \\
\hline - Open mindedness & $4,13,21,25$ & 28 & & & \\
\hline - Critical thinking & $2,6,16$ & 11 & & & \\
\hline Cooperation & 14 & 23,18 & & & \\
\hline Honesty & 9,19 & 24 & & & \\
\hline Persistency & 1,3 & 12,22 & & & \\
\hline
\end{tabular}


The qualitative data of students' scientific attitudes and the perceptions was collected by interviewing the students and the teachers during and after the implementation of innovative green garden-based education. The respondents of the interview were seven students that were selected randomly and four science teachers. The interview was conducted with each person using semi-structured interview models. The researcher asked about 5 main questions (Table 2) toward the implementation of innovative green garden-based education. The questions were developed based on the information that the researcher needed.

Table 2. The main interview questions

\begin{tabular}{cl}
\hline No. & \multicolumn{1}{c}{ The main questions } \\
\hline 1. & What do you feel during the implementation of green garden-based education? \\
2. & What are the strengths of the implementation of green garden-based education? \\
3. & What are the weaknesses of the implementation of green garden-based education? \\
4. & Please explain your experiences what you have learned during the implementation of green garden-based education? \\
5. & What do you want to learn during the implementation of green garden-based education? \\
6. & What are your suggestions for the next program related with the implementation of green garden-based education? \\
\hline
\end{tabular}

\section{RESULTS AND DISCUSSION}

The school garden movement has grown as tools for helping teacher teach hands-on experience and improve healthy eating behaviors. It share philosophies of learning with experiential learning, environmental awareness, ecological literacy, and agricultural literacy (Wells et al., 2015). It provides dynamic environments that help the students to observe, discover, investigate, and learn. These practically activities can lead to the development of students scientific attitude (Balaji, 2017; Erdogan, 2017). Many studies on scientific attitude have been done but study about the scientific attitude of student during the implementation of innovative green garden- based education in Indonesia has not been explained much. This study focused on the students' scientific attitude and the perceptions of student and teacher toward the implementation on green garden based-education that implement in the junior high school 8 Salatiga. The data was gathered through questionnaire and interview methods.

The students' scientific attitude toward the implementation of green garden based-education innovative green garden-based education

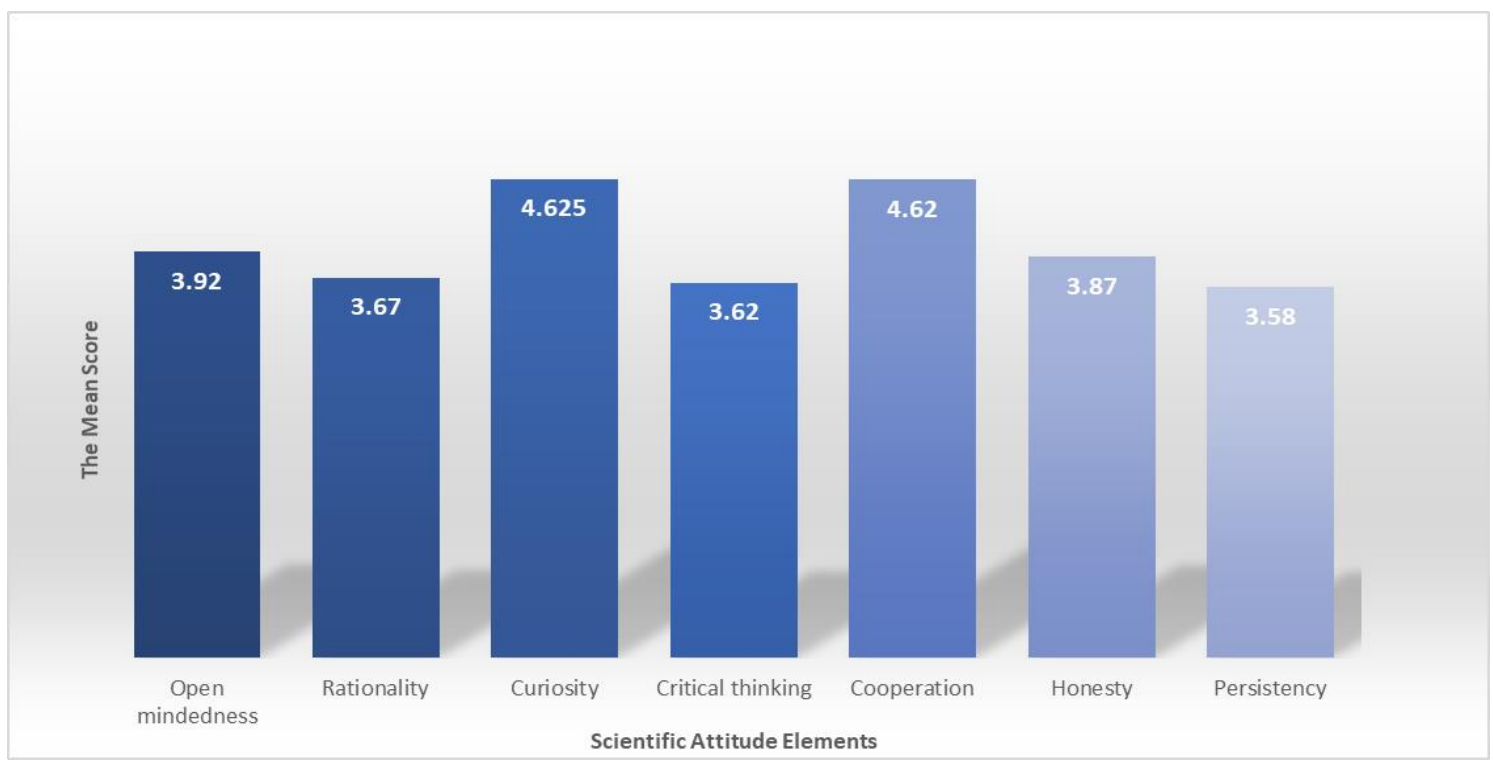

Figure 1. The mean score of each student's scientific attitude elements

In general, Figure 1 shows that there is positive student's scientific attitude toward the implementation of innovative green garden-based education. It can be concluded from the mean score of all elements is more than 3.1. The highly positive attitude can be shown in curiosity and cooperation elements, and moderately positive in open-mindedness, rationality, critical thinking, honesty and persistency. The highest mean score is 
curiosity and the lowest mean score is persistency attitude. The former research by Greer, Rainville, Knausenberger, \& Sandolo (2019) also concluded that garden based-learning can promote positive attitudes toward learning. Based on the analysis of each item statement related to students' scientific elements in Table 3 , it can be noted that all items included positive attitude starting from slightly positive to highly positive attitude with 3.2 as the lowest mean score and 4.7 as the highest mean score. Both of quantitative and qualitative data presented consistently that the respondents agree that the implementation of innovative green garden-based education has many advantages for learning science. The activities can lead to positive students' scientific attitude.

Table 3 described the highly positive attitude elements are curiosity and cooperation elements. Curiosity developed when students have to observe the environment directly. They wanted to know what the cause of a phenomenon is. Various questions arose and they tried to find the answers through asking the teacher or looking in books or other resources. Curiosity is considered to stimulate exploratory behavior. It leads to develop sensory data input. A curious person asks questions, read information, and carries out investigation (Pitafi et al., 2012). Cooperation develops when students have to work in groups. The students realized that they have responsibility to reach their goal together. School gardening builds the social well-being impacts. The personal well-being impact such as enjoyment and feeling of achievement, satisfaction, and pride from nurturing the plants, observing them grow and harvested the crops. These initiate the sense of connection to nature, empathy, and care in terms of how they interact with people. Gardening can eliminate some of the social boundaries (Mcclintic \& Petty, 2015; Ohly et al., 2016). The student participation in garden program helps students refine teamwork skills, and self-understanding. It develops the ability to make decisions and communicate. School garden also provides possibilities for building up social competences, improve the relationships and communication among the students and also with the teachers (Dawson, Richards, Collins, Reeder, \& Gray, 2013; Slabe, 2017)

The scientific attitude elements that include in moderately positive attitude are open-mindedness, rationality, critical thinking, honesty and persistency. All of these attitudes can be formed through the activities that were conducted based on science methods. The students with open-mindedness attitude willing to change his mind based on reliable evidence and the respects another's point of view. The students built trust from the results of the researches that follow scientific processes. They also considered the different idea if they get the evidence. Learning through innovative green garden-based education can develop rationality and critical thinking. These attitude guides the scientists' behavior throughout the investigation about where is the source of his knowledge come. The student habit of looking for natural causes and for natural events is developed. The honesty attitude is concerned with the conscious act of truthfully reporting observations. Then, they were enabled to discover the concept and solve the problems and obstacles that they faced during the innovative green garden-based education course. Students participated to reflect the knowledge and experiences in a daily journal. They gained knowledge and empowered to try a new behavior (Greer et al., 2019; Pitafi \& Farooq, 2012). The implementation of innovative green garden-based education is a great tool to enhance understanding of sustainable development. Growing the plants enables the development of a deeper knowledge about food production and the importance of sustainable management (Cutter-mackenzie \& Edwards, 2013; Lochner, Rieckmann, \& Robischon, 2019; Slabe, 2017). The Mean Score of the Students Scientific Attitude based on Each Statement can be seen in Table 3.

In this research, the innovative green garden-based education characteristics adopted by school garden initiated by FAO (2009). The activity started with the introduction of characters from plants specifically for morphological characteristics. The morphological characteristic can be recognized by observing plant growth type, plant size, stem pubescence density and length, leaf type, corolla color, the color of immature and mature fruit, seed shape and color. It is a basic concept that important to know if we want to learn about plant (Chime, Aiwansoba, Osawaru, \& Ogwu, 2017; Wolsey \& Lapp, 2014).

Students learned to distinguish the types of plants and about the plants classification. Then, students learned about how to cultivate the plants. Students practiced hands-on experience after mastering the concept. Students were given seeds based on the selected plants that they are interested, including: tomatoes, chilies, spinach, watermelons, mustard greens, melons, ginger. They planted many kinds of plants in groups. The students used the various planting media, including wall gardens, raised bed, pots, and verticulture that contain soil, husks, organic fertilizer. Each group was responsible for each plant that they planted. During the course, each group had different experiences depending on the type of plants and soil media used. Students were asked to observe the plants' growth whether plants are grown well or not. Students also learned to provide organic compost using the vermicompos that has been provided. The students observed the plants and pests that appear along the plants growth. They also observed the morphological characteristic of each pest. If the students got problems or obstacles in the process of planting they might work together with their friends or ask the teacher for help as a facilitator. All of the observation results were recorded in a module. Observations were 
carried out until the time the plants were ready to be harvested. At the end of the program students could harvest garden products and process them for sale or for consumption.

Table 3. The mean score of the students scientific attitude based on each statement

\begin{tabular}{|c|c|c|c|}
\hline $\begin{array}{l}\text { The scientific } \\
\text { attitude elements }\end{array}$ & Number of item & The statements & Mean score \\
\hline \multirow[t]{4}{*}{ Curiosity } & 20. & $\begin{array}{l}\text { The researches we do in the innovative green garden-based } \\
\text { education course are boring for me }\end{array}$ & 4.7 \\
\hline & 10. & I am willing to do research on natural events & 4.7 \\
\hline & 27. & $\begin{array}{l}\text { I have many questions in relation to the activities during the } \\
\text { innovative green garden-based education course }\end{array}$ & 4.4 \\
\hline & 8 & $\begin{array}{l}\text { I want to know about the characteristic of plants and how to } \\
\text { growth the plants well }\end{array}$ & 4.7 \\
\hline \multirow[t]{5}{*}{ Rationality } & 15. & I do not believe about a fact before I have the evidence & 3.6 \\
\hline & 5. & $\begin{array}{l}\text { I always form my result reports based on observations and } \\
\text { experiments }\end{array}$ & 4.2 \\
\hline & 17. & Using scientific methods help me think correctly. & 3.9 \\
\hline & 7. & I can logically interpret my experiment results. & 3.2 \\
\hline & 26. & I use scientific processes to decide correctly. & 3.5 \\
\hline \multirow[t]{5}{*}{ Open mindedness } & 28. & $\begin{array}{l}\text { I think scientific and technologic inventions are } \\
\text { hazardous rather than beneficial. }\end{array}$ & 3.9 \\
\hline & 25. & $\begin{array}{l}\text { I trust the results of the researches following scientific } \\
\text { processes. }\end{array}$ & 4.1 \\
\hline & 4. & $\begin{array}{l}\text { I can use appropriate resources for the solution of the } \\
\text { problems I face during innovative green garden-based } \\
\text { education course. }\end{array}$ & 3.9 \\
\hline & 13. & $\begin{array}{l}\text { The innovative green garden-based education courses help me } \\
\text { consider other's thoughts during decision making }\end{array}$ & 4.1 \\
\hline & 21. & $\begin{array}{l}\text { I accept the results written in books if they are different from my } \\
\text { experiment results. }\end{array}$ & 3.6 \\
\hline \multirow[t]{4}{*}{ Critical thinking } & 2. & I can easily compose questions related to my research topic. & 3.2 \\
\hline & 6. & I can look at my experiment results with a critical eye. & 3.2 \\
\hline & 16. & $\begin{array}{l}\text { What I learn in innovative green garden-based education } \\
\text { course helps me explain my opinions easily to the other } \\
\text { people. }\end{array}$ & 4.1 \\
\hline & 11. & I do not care about my research result & 3.9 \\
\hline \multirow[t]{3}{*}{ Cooperation } & 23. & $\begin{array}{l}\text { I do not care about my friends' opinions in discussions during } \\
\text { the innovative green garden-based education course }\end{array}$ & 4.4 \\
\hline & 18. & $\begin{array}{l}\text { I prefer working alone rather than working with my friends on } \\
\text { topics that I need to do research. }\end{array}$ & 4.7 \\
\hline & 14. & I always ask my friends to help me if I have a problem & 4.7 \\
\hline \multirow[t]{3}{*}{ Honesty } & 9. & $\begin{array}{l}\text { I always write exactly what I observe about the experiments } \\
\text { that I do. }\end{array}$ & 4.4 \\
\hline & 19. & I never cheat to my friend when I collect the data & 3.4 \\
\hline & 24. & $\begin{array}{l}\text { Sometimes, I do not say the truth to my teacher or my friend } \\
\text { during the innovative green garden-based education course }\end{array}$ & 3.8 \\
\hline \multirow[t]{4}{*}{ Persistency } & 12. & $\begin{array}{l}\text { I can give up my work if it is too long and requirement much } \\
\text { effort }\end{array}$ & 3.6 \\
\hline & 22. & $\begin{array}{l}\text { I think I cannot manage to do the tasks I am assigned to during } \\
\text { the innovative green garden-based education course. }\end{array}$ & 3.6 \\
\hline & 3. & I can easily handle the problems I face during my researches. & 3.5 \\
\hline & 1. & $\begin{array}{l}\text { I always follow the methods during the course which are similar } \\
\text { to scientist's works. }\end{array}$ & 3.6 \\
\hline
\end{tabular}

Source: adopted from Yasar and Anagun (2009) and Pitafi et.al (2012).

In general, school garden has common focus on growing plants in a few pots or in schoolyard. Gardening programs are flexible in all shapes and sizes fit with the needs and resources of every school (Alderson et al., 2015). The International Institute for Rural Reconstruction describe that it is needed some features to promote school garden resilience: school garden must use organic fertilizer, must have at least $200-\mathrm{m}^{2}$ garden bed and deep dug at least $1 \mathrm{ft}$, good water source, proper drainage system, and use mulch to protect soil (AngelesAgdeppa, Monville-Oro, Gonsalves, \& Capanzana, 2019; De Vlieger, Riley, Miller, Collins, \& Bucher, 2018). Running a school garden requires some knowledge, people skills, and common sense that related with how to 
plan and manage, find resources, collaborate and motivate with those involved, and organize garden work and lessons (FAO, 2009; Sherman, 2010).

\section{The perception of teachers and students toward the implementation of green garden based-education innovative green garden-based education}

Learning science through innovative green garden-based education helps the student to work as scientist. They can collect the data through scientific methods including observing, measuring, experimenting, analyzing, and concluding. It gives experience for students to be able to apply concepts obtained in the classroom to the real world. The activities in gardens can increase the scientific attitude of the student because gardens can be used as living laboratories where students observe what they are learning and implement the knowledge (Erdogan, 2017; Greer et al., 2019; Passy, 2012)

Consistently, the perceptions of teachers and students figured that there are many positive effects of the innovative green garden-based education implementation. The activities lead to hands-on experience and engage high order thinking skill. The teacher emphasizes that the innovative green garden-based education can provide a hands-on learning. They can apply their knowledge to real world situations (Humberstone \& Stan, 2011). Outdoor experiences engage high order thinking skill and the understanding about the concept. The activities also help students improve their scientific attitude in relation to rationality, curiosity, critical thinking, and persistency. According to Revati \& Meera (2017) science teachers have to know the importance of making connection between science and student's life. The learning of science should emphasize on activities that enhance student's experiences in order to relate it to their daily life. The teacher should organize learning environment which has positively effect for scientific attitudes (Balaii, 2017; Erdogan, 2017; Prince, 2019). By doing this, students can realize that their knowledge are important and valued. They can improve their selfconcept in science. Teachers find the garden is a moderately to very effective tool for teaching science. 3 aspects of school gardens as opportunities to address time- and staff-related issues: strengthening of garden committees, professional development, and community outreach (Burt, Luesse, Rakoff, Ventura, \& Burgermaster, 2018). But there are some limitations based on teacher perception of the innovative green garden-based education implementation such as time consuming and requiring wide and large spaces. Selected responses regarding the implementation of innovative green garden-based education by the teachers and students can be seen in Table 4 and Table 5.

Table 4. Selected responses regarding the implementation of innovative green garden-based education by the teachers

Theme: The strength and the weakness of the implementation of innovative green garden-based education and the students scientific attitude toward the implementation of innovative green garden-based education

Learning science in innovative green garden-based education can motivate the students to and give the real experience related to the science concept (rationality).

Some activities are time consuming. The teacher must well prepared to manage activities based on innovative green garden-based education module so that the activities is conducted effectively

There are many questions is asked by the student during the innovative green garden-based education activities (curiosity, critical thinking)

The activities help students have responsibility for their tasks, promote their critical thinking and problem solving (persistency, critical thinking)

It will be a benefit for school that has wide and large area, but it will difficult for school with the limited area.

Table 5. Selected responses regarding the implementation of innovative green garden-based education by the students

Theme: The strength and the weakness of the implementation of innovative green garden-based education and the students scientific attitude toward the implementation of innovative green garden-based education

I feel that gardening is one of the way to learm about science in real way, we are not only sit and listen the explanation from our teacher, but also we do many interesting activities

I like to cooperate with the other friend when I did my task in during innovative green garden-based education (cooperation)

Learning science through innovative green garden-based education is very interesting (curiosity)

Sometimes, I still feel shy to express my opinion in front of the others in class but this activity encourage me to ask and express my opinion (curiosity and critical thinking)

I think worms is harmful for us, actually I just know that the worm has many benefit for environment (open mindedness)

I want to know why the plants has different growth in size although located in the same media (curiosity)

I listen carefully to our gardening teacher (persistency)

The students state that the activities during the innovative green garden-based education course develop their scientific attitude including cooperation, curiosity, critical thinking, open mindedness, and persistency. They feel more interested in outclass activities than classroom activities. They are encouraged to work in teams 
and explore the phenomenon that is happening. The students prefer learning with outdoor activity than just only staying in the classroom (Maynard, Waters, \& Clement, 2013b). Garden-based education can capture students' interest and energize their learning. The learning outcome of students who joined in a hands-on school gardening program was higher than the students who did not participate in gardening activities (Greer et al., 2019; Maynard, Waters, \& Clement, 2013a). Many aspects to consider when comparing outdoor educational settings; the comparison of purposes, aims, pedagogy, outcomes, (Almers, Askerlund, \& Kjellström, 2017). Skinner (2015) states that the engagement in the garden is positively and significantly correlated with student self- perceptions, competence, autonomy, intrinsic motivation, and school achievement. Similarly with the study conducted by Hammarsten,et.al (2019) about the student's perspectives on a forest garden, they have positive feelings on a forest garden including the activities caring for the organism living there. It can develop the ecological literacy: practical competence, learning how to co-exist and care, and biological knowledge and ecological understanding.

The implementation of garden programs also significantly influences students' environmental attitudes (Malberg \& Wistoft, 2018; Wolsey \& Lapp, 2014; Verde \& Valdés, 2013). The former research on school gardens indicates a positive reaction toward nutrition habits when implemented into the curriculum (Hamulka, Wadolowska, Hoffmann, Kowalkowska, \& Gutkowska, 2018). The students have the ability to change their attitudes through garden programs (Mccarty, 2013; Murakami, Su-russell, \& Manfra, 2017; Wolsey \& Lapp, 2014).

However, there are some limitations of the implementation of innovative green garden-based education such as time consuming and in some case, it need a wide green area. The school that applies green gardenbased education must be well-prepared so that the course is conducted effectively. Kupolati, Macintyre, Gericke, \& Becker (2019) said that there is no universal model of green garden based-education that can be implemented to every community. Each culture or community has to design a plan that addresses the needs of its learners and educators (Greer et al., 2019). By applying the hands-on curriculum enhance students' interest in science with no loss of science content (Sheldrake, Mujtaba, \& Reiss, 2017). The sustainability of the implementation of green garden based-education should be a responsibility of multiple stakeholders across the school (Duram \& Williams, 2015). The conceptual model of potential effect of school garden program that explain about short-term, long-term effect, and the interconnections between individual, family, school and community-level effects can be considered (Clague, 2018; Davis, Spaniol, \& Somerset, 2015; Ohly et al., 2016).

\section{CONCLUSION}

The students have positive attitude toward the implementation of innovative green garden-based education with highly positive attitude in curiosity and cooperation elements, and moderately positive in openmindedness, rationality, critical thinking, honesty and persistency. The teacher and students emphasize many advantages during the implementation of innovative green garden-based education for learning science especially in forming positive scientific attitude and giving hands-on experiential learning. Based on the findings of this study, the science teacher should facilitate students for learning science not only in the classroom but in the real environment. The green garden based-education curricula can be one alternative as an innovative educational tool for learning science.

\section{REFERENCES}

Alderson, T., Hempel, J., \& Olson, P. (2015). Gardens for learning (Vol. 3). Canada: California School Garden Network. Retrieved from http://www.csgn.org/sites/default/files/CSGN_book.pdf

Almers, E., Askerlund, P., \& Kjellström, S. (2017). Why forest gardening for children? Swedish forest garden educators' ideas, purposes, and experiences. The Journal of Environmental Education, 49(3), 242-259. doi: https://doi.org/10.1080/00958964.2017.1373619

Angeles-Agdeppa, I., Monville-Oro, E., Gonsalves, J. F., \& Capanzana, M. V. (2019). Integrated school based nutrition programme improved the knowledge of mother and school children. Maternal and Child Nutrition, 15(3), 1-9. doi: https://doi.org/10.1111/mcn.12794

Balaji, G. (2017). Role of science teacher in developing scientific attitude among secondary school students. Scholarly Research Journal for Interdisciplinary Studies, 4(37), 1-7. doi: https://doi.org/10.21922/srjis .v4i37.10552 
Bento, G., \& Dias, G. (2017). The importance of outdoor play for young children's healthy development. Porto Biomedical Journal, 1-4. doi: https://doi.org/10.1016/j.pbj.2017.03.003

Best, N. B., Hartwig, T., Budka, J. S., \& Brandon, J. (2014). Soilless plant growth media influence the efficacy of phytohormones and phytohormone inhibitors. Plos One, 9(12), 1-24. doi: https://doi.org/10.1371 /journal.pone.0107689

Burt, K. G., Luesse, H. B., Rakoff, J., Ventura, A., \& Burgermaster, M. (2018). School gardens in the united states: Current barriers to integration and sustainability. American Journal of Public Health, 108(11), 1543-1549. doi: https://doi.org/10.2105/AJPH.2018.304674

Chime, A. O., Aiwansoba, R. O., Osawaru, M. E., \& Ogwu, M. C. (2017). Morphological evaluation of tomato (Solanum lycopersicum Linn.) Cultivars. Makara Journal of Science, 21(2), 97-106. doi: https://doi.org /10.7454/mss.v21i2.7421

Clague, L. (2018). Thinking outside the circle: Reflections on theory and methods for school-based garden research. The Australian Journal of Indigenous Education, 1-7. doi: https://doi.org/10.1017/jie.2017.21

Cutter-mackenzie, A., \& Edwards, S. (2013). Toward a model for early childhood environmental education: Foregrounding, developing, and connecting knowledge through play- based learning. The Journal of Environmental Education, 44(3), 37-41. doi: https://doi.org/10.1080/00958964.2012.751892

Davies, R., \& Hamilton, P. (2016). Assessing learning in the early years' outdoor classroom: Examining challenges in practice. Education 3-13, 46(1), 117-129. doi: https://doi.org/10.1080/03004279.2016. 1194448

Davis, J. N., Spaniol, M. R., \& Somerset, S. (2015). Review article sustenance and sustainability: Maximizing the impact of school gardens on health outcomes. Public Health Nutrition, 18(13), 2358-2367. doi: https://doi.org/10.1017/S1368980015000221

Dawson, A. A., Richards, R. A., Collins, C. A., Reeder, A. I. A., \& Gray, A. B. (2013). Edible gardens in early childhood education settings in Aotearoa, New Zealand. Health Promotion Journal of Australia, 24, 214-218. doi: https://doi.org/10.1071/HE13066

De Vlieger, N., Riley, N., Miller, A., Collins, C. E., \& Bucher, T. (2018). Nutrition education in the Australian New South Wales primary school curriculum: An exploration of time allocation, translation and attitudes in a sample of teachers. Health Promotion Journal of Australia, 1-8. doi: https://doi.org/10.1002/hpja. 188

Duram, L. A., \& Williams, L. L. (2015). Growing a student organic garden within the context of university sustainability initiatives. International Journal of Sustainability in Higher Education, 16(1), 3-15. doi: https://doi.org/10.1108//JSHE-03-2013-0026

Erdogan, S. C. (2017). Science teaching attitudes and scientific attitudes of pre-service teachers of gifted students. Journal of Education and Practice, 8(6), 164-170. Retrieved from https://files.eric.ed.gov/ fulltext/EJ1133039.pdf

FAO. (2009). Setting up and running a school garden: A manual for teachers, parents and communities. Retrieved from http://www.fao.org/3/a0218e/a0218e00.htm

Greer, A. E., Rainville, K., Knausenberger, A., \& Sandolo, C. (2019). Opportunities for school garden-based health education in a lower-income, diverse, erban school district. American Journal of Health Education, 50(4), 257-266. doi: https://doi.org/10.1080/19325037.2019.1616010

Grunert, O., Hernandez-sanabria, E., Vilchez-vargas, R., \& Jauregui, R. (2016). Mineral and organic growing media have distinct community structure, stability and functionality in soilless culture systems. Scientific Reports, 1-14. doi: https://doi.org/10.1038/srep18837

Hammarsten, M., Askerlund, P., Almers, E., Avery, H., \& Samuelsson, T. (2019). Developing ecological literacy in a forest garden: Children's perspectives. Journal of Adventure Education \& Outdoor Learning, 19(3), 227-241. doi: https://doi.org/10.1080/14729679.2018.1517371

Hamulka, J., Wadolowska, L., Hoffmann, M., Kowalkowska, J., \& Gutkowska, K. (2018). Effect of an education program on nutrition knowledge, attitudes toward nutrition, diet quality, lifestyle, and body composition in Polish teenagers. The ABC of healthy eating project: Design, protocol,and methodology. Nutrients, 10(10), 1-23. doi: https://doi.org/10.3390/nu10101439

Harris, F. (2015). The nature of learning at forest school: Practitioners' perspectives. Education 3-13, 45(2), 272-291. doi: https://doi.org/10.1080/03004279.2015.1078833 
Harris, R., \& Bilton, H. (2018). Learning about the past: Exploring the opportunities and challenges of using an outdoor learning approach challenges of using an outdoor learning approach. Cambridge Journal of Education, 1-23. doi: https://doi.org/10.1080/0305764X.2018.1442416

Humberstone, B., \& Stan, I. (2011). Outdoor learning: Primary pupils' experiences and teachers' interaction in outdoor learning. Education 3-13, 39(5), 529-540. Doi: https://doi.org/10.1080/03004279.2010.487837

Kaur, G. (2013). Scientific attitude in relation to critical thinking among teachers. Educationia Confab, 2(8), 24-29. Retrieved from https://pdfs.semanticscholar.org/0fe1/8ac4f38873a503cde65708e7d155204bc 8c3.pdf

Kennedy, J., Quinn, F., Taylor, N., Quinn, F., \& Taylor, N. (2016). The school science attitude survey: A new instrument for measuring attitudes towards school science measuring attitudes towards school science. International Journal of Research \& Method in Education, 39(4), 422-445. doi: https://doi.org/10.1080/ 1743727X.2016.1160046

Kim, S., \& Park, S.-A. (2020). Garden-based integrated intervention for improving children's eating behavior for vegetables. International Journal of Environmental Research and Public Health, 17(4), 1-14. doi: https://doi.org/10.3390/ijerph17041257

Korur, F. (2016). Attitude toward science teaching of spanish and turkish in service elementary teachers: Multi group confirmatory factor analysis. Eurasia Journal of Mathematics, Science \& Technology Education, 12(2), 303-320. doi: https://doi.org/10.12973/eurasia.2016.1215a

Kupolati, M. D., Macintyre, U. E., Gericke, G. J., \& Becker, P. (2019). A contextual nutrition program improves nutrition knowledge and attitudes of South African teachers and learners. Frontiers in Public Health, 7, 1-12. doi: https://doi.org/10.3389/fpubh.2019.00258

Lacap, M. P. (2015). The scientific attitudes of students major in science in the new teacher education curriculum. Asia Pacific Journal of Multidisciplinary Research, 3(5), 7-15. Retrieved from http://oaji.net/articles/2016/1543-1464848419.pdf

Leuven, J. R. F. W., Rutenfrans, nnerie H. M., Dolfing, lexander G., \& Leuven, R. S. E. W. (2018). School gardening increases knowledge of primary school children on edible plants and preference for vegetables. Food Science \& Nutrition, 1960-1967. doi: https://doi.org/10.1002/fsn3.758

Lochner, J., Rieckmann, M., \& Robischon, M. (2019). Any sign of virtual School garden exchanges? education for sustainable development in school gardens since 1992: A systematic literature review. Any Sign of Virtual School Garden Exchanges?169Journal of Education for Sustainable Development, 13(2), 168192. doi: https://doi.org/10.1177/0973408219872070

Macquarrie, S. (2016). Everyday teaching and outdoor learning: Developing an integrated approach to support school-based provision integrated approach to support school-based provision. Education 3-13, 46(3), 345-361. doi: https://doi.org/10.1080/03004279.2016.1263968

Malberg Dyg, P., \& Wistoft, K. (2018). Wellbeing in school gardens the case of the gardens for Bellies food and environmental education program. Environmental Education Research, 1-16. doi: https://doi.org/ 10.1080/13504622.2018.1434869

Maynard, T., Waters, J., \& Clement, J. (2013a). Child-initiated learning, the outdoor environment and the underachieving' child. Early Years, 33(3), 212-225. doi: https://doi.org/10.1080/09575146.2013.771152

Maynard, T., Waters, J., \& Clement, J. (2013b). Moving outdoors: Further explorations of' child-initiated' learning in the outdoor environment. Education 3-13, 41(3), 282-299. doi: https://doi.org/10.1080/03004 279.2011.578750

Mccarty, J. (2013). REAL school gardens program: Learning gardens and teacher training to improve student engagement and academic performance in low performing elementary schools. Journal of Applied Research on Children: Informing Policy ForChildren at Risk, 4(2), 1-8. Retrieved from https://files.eric. ed.gov/fulltext/EJ1188881.pdf

Mcclintic, S., \& Petty, K. (2015). Exploring early childhood teachers' beliefs and practices about preschool outdoor play: A qualitative study. Journal of Early Childhood TeacherEducation, 36(1), 24-43. doi: https://doi.org/10.1080/10901027.2014.997844

Morgan, P. J., Warren, J. M., Lubans, D. R., Saunders, K. L., Quick, G. I., \& Collins, C. E. (2017). The impact of nutrition education with and without a school garden on knowledge, vegetable intake and preferences and quality of school life among primary school students. Public Health Nutrition, 13(11), 1931-1940. doi: https://doi.org/10.1017/S1368980010000959 
Murakami, C. D., Su-russell, C., \& Manfra, L. (2017). Analyzing teacher narratives in early childhood gardenbased education education. The Journal of Environmental Education, 1-12. doi: https://doi.org/10.1080/ 00958964.2017 .1357523

Nolan, G. A., Mcfarland, A., Zajicek, J. M., \& Waliczek, T. M. (2012). The effects of nutrition education and gardening on attitudes, preferences, and knowledge of minority second to fifth graders in the Rio Grande Valley toward fruit and vegetables. HortTechnology, 22(3), 299-304. doi: https://doi.org/ 10.21273/HORTTECH.22.3.299

Ohly, H., Gentry, S., Wigglesworth, R., Bethel, A., Lovell, R., \& Garside, R. (2016). A systematic review of the health and well-being impacts of school gardening: Synthesis of quantitative and qualitative evidence. BMC Public Health, 16(1). doi: https://doi.org/10.1186/s12889-016-2941-0

Passy, R. (2012). School gardens: Teaching and learning outside the front door. Education 3-13, 42(1), $23-$ 38. doi: https://doi.org/10.1080/03004279.2011.636371

Pitafi, A. I., Pur, R., \& Farooq, M. (2012). Measurement of scientiific attitude of secondary school students in Pakistan. Academic Research International, 2(2), 379-392. Retrieved from http://www.savap.org.pk/ journals/ARInt./Nol.2(2)/2012(2.2-43).pdf

Prince, H. E. (2018). Changes in outdoor learning in primary schools in England, 1995 and 2017: Lessons for good practice. Journal of Adventure Education and Outdoor Learning, 1-14. doi: https://doi.org/10.1080 /14729679.2018.1548363

Prince, H. E. (2019). The sustained value teachers place on outdoor learning The sustained value teachers place on outdoor learning. Education 3-13, 1-14. doi: https://doi.org/10.1080/03004279.2019.1633376

Revati, N., \& Meera, K. P. (2017). An investigation of scientific attitude among secondary school students in Kottayam district of Kerala. Journal of Research \& Method in Education, 7(1), 63-66. doi: https://doi. org/10.9790/7388-0701036366

Sheldrake,S., Mujtaba, T., \& Reiss, M., J. (2017). Science teaching and students' attitude and aspiration: The importance of converying the applications and relevance of science. International Journal of Educational Research, 85, 167-183. doi: https://dx.doi.org/10.1016/j.ijer.2017.08.002

Sherman, J. (2010). A new deal for school gardens. FAO (Vol. 61). doi: https://doi.org/10.1038/061455a0

Skinner, E. (2015). Intrinsic motivation and engagement as "active ingredients" in garden-based education: Examining models and measures derived from self-determination theory. The Journal of Environmental Education, 43(1), 16-36. doi: https://doi.org/10.1080/00958964.2011.596856

Slabe, A. (2017). School garden guide. Ljubljana: Institute for Sustainable Development. Retrieved from https://eathink2015.org/el/download/School-Garden-Guide-WEB.PDF

Soga, M., Gaston, K. J., \& Yamaura, Y. (2016). Gardening is beneficial for health: A meta-analysis. Preventive Medicine Reports, 5, 92-99. doi: https://doi.org/10.1016/j.pmedr.2016.11.007

Somerset, S., \& Markwell, K. (2017). Impact of a school-based food garden on attitudes and identification skills regarding vegetables and fruit: A 12 month intervention trial. Public Health Nutrition, 12(2), 214221. doi: https://doi.org/10.1017/S1368980008003327

Triador, L., Farmer, A., Maximova, K., Willows, N., \& Kootenay, J. (2015). Research brief a school gardening and healthy snack program increased aboriginal first nations children's preferences toward vegetables and fruit. Journal of Nutrition Education and Behavior, 47(2), 176-180. doi: https://doi.org/10.1016/j. jneb.2014.09.002

Ural, E., \& Durdu Mehmet Gençoğlan. (2020). The effect of argumentation-based science teaching approach on 8th graders' learning in the subject of acids-bases, their attitudes towards science class and scientific process skills. Interdisciplinary Journal of Environmental and Science Education, 16(1), 1-15. doi: https://doi.org/10.29333/ijese/6369

Verde, A., \& Valdés, A. (2013). Garden-based learning: An experience with "at risk" secondary education students. The Journal of Environmental Education, 44(4), 37-41. doi: https://doi.org/10.1080/00958964. 2013.786669

Wells, N. M., Myers, B. M., Todd, L. E., Barale, K., Gaolach, B., Ferenz, G., ... Franz, N. K. (2015). The effects of school gardens on children's science knowledge: A randomized controlled trial of low-income elementary schools. International Journal of Science Education, 37(17), 2858-2878. doi: https://doi. org/10.1080/09500693.2015.1112048 
Wolsey, T. D., \& Lapp, D. (2014). School gardens: Situating students within a global context. Journal of Education, 194(3), 53-60. doi: https://doi.org/10.1177/002205741419400306

Yasar, Sefik, \& Anagun, S. S. (2009). Reliability and validity studies of the science and technology course scientific attitude scale. Journal of Turkish Science Education, 6(2), 43-54. Retrieved from https://www.researchgate.net/publication/26645392_Reliability_and_Validity_Studies_of_the_Science_a nd_Technology_Course_Scientific_Attitude_Scale 